Sains Malaysiana 49(8)(2020): 1799-1808

http://dx.doi.org/10.17576/jsm-2020-4908-04

\title{
Integration of Fish Culture in Hydroponic Agriculture in Flood-Prone Areas
}

(Integrasi Pengkulturan Ikan dalam Pertanian Hidroponik dalam Kawasan Mudah Banjir)

\author{
Md. Shakhawate Hossain* \& MD. Jahangir Alam
}

\begin{abstract}
Floating bed organic cultivation of different vegetables, flowers, and seedlings have been shown a promising means of agricultural crop production in different wetland areas of Bangladesh. The present study was aimed at finding out the suitability of the integration of fish in this system in waterlogged areas. The experiment consists of three treatments namely SB, silver barb Barbonymus gonionotus; T, tilapia Oreochromis niloticus; and SBT, tilapia: silver barb (1:1 ratio) with three replications of $6.75 \mathrm{~m}^{2}$ floating vegetable beds in each. Fish were stocked at a rate of $3 \mathrm{~m}^{-2}$ for five months of culture and fed at 1.5\% of body weight twice daily. Over the study period, water quality parameters and fish survival rate did not vary significantly among different treatments. Tilapia showed significantly higher daily and specific growth rates in mono- and polyculture, but silver barb only in polyculture system. Thus, total fish production in $\mathrm{kg} \mathrm{ha}^{-1}$ was significantly higher in treatments $T(p=0.001)$ and SBT $(p=0.001)$ than SB. Vegetable production was not significantly different among treatments. In the financial analysis, the benefit-cost ratio of different treatments was $>1$, indicating that investment was financially profitable for all treatments, but treatment $T$ and $S B T$ were more profitable. Therefore, we can conclude that integrating fish with floating bed agriculture systems could be an ideal approach to generate alternate income activities and mitigate climate change effects among disaster-prone waterlogged regions of Bangladesh.
\end{abstract}

Keywords: Aquaculture; Barbonymus gonionotus; floating bed agriculture; Oreochromis niloticus; vegetable production

\section{ABSTRAK}

Penanaman organik berlapis secara terapung daripada sayur-sayuran, bunga-bunga dan biji benih yang berbeza telah ditunjukkan sebagai kaedah yang berpotensi untuk penghasilan produk pertanian dalam kawasan tanah basah yang berbeza di Bangladesh. Kajian ini bertujuan untuk menemukan kesesuaian integrasi ikan di sistem ini dalam kawasan tanah berair. Kajian ini mengandungi tiga rawatan iaitu SB lampam jawa Barbonymus gonionotus; $T$, tilapia Oreochromis niloticus; dan SBT, tilapia: lampam jawa (nisbah 1:1) dengan tiga replikasi daripada setiap 6.75 $\mathrm{m}^{2}$ sayuran berlapis yang terapung. Ikan distok pada kadar $3 \mathrm{~m}^{-2}$ selama 5 bulan pengkulturan dan diberi makan sebanyak $1.5 \%$ daripada berat badannya sebanyak dua kali sehari. Sepanjang tempoh kajian, parameter kualiti air dan kadar kelangsungan hidup ikan tidak menunjukkan variasi yang ketara antara kaedah yang berbeza. Tilapia menunjukkan kadar pertumbuhan khusus harian yang lebih tinggi dan ketara dalam pengkulturan mono dan poli, tetapi lampam jawa hanya pada sistem pengkulturan poli. Oleh itu, penghasilan ikan keseluruhan dalam $\mathrm{kg} \mathrm{ha}^{-1}$ adalah lebih ketara tinggi dalam rawatan $T(p=0.001)$ dan $S B T(p=0.001)$ daripada SB. Penghasilan sayuran adalah tidak ketara antara rawatan. Analisis kewangan menunjukkan nisbah faedah-kos daripada rawatan yang berbeza adalah >1, menunjukkan bahawa pelaburan adalah menguntungkan daripada segi kewangan untuk kesemua rawatan, tetapi rawatan T dan SBT adalah lebih menguntungkan. Oleh itu, kami dapat menyimpulkan bahawa integrasi ikan dengan sistem pertaninan berlapis secara terapung boleh menjadi pendekatan yang ideal untuk menjana punca pendapatan alternatif dan mengurangkan kesan perubahan iklim antara kawasan yang mudah terkesan dengan bencana tanah berair di Bangladesh.

Kaa kunci: Akuakultur; Barbonymus gonionotus; penghasilan sayuran; pertanian berlapis terapung; Oreochromis niloticus

\section{INTRODUCTION}

Bangladesh is a flood-prone country because the drainage channels of the Ganges, Brahmaputra and Meghna Rivers, which flow through the country. Besides,
Bangladesh is highly vulnerable to the adverse effect of global climate change due to its geographic position (IPCC 2012). Every year, during monsoon, from June to October, the flow of these rivers and local runoff outstrips the capacity of the channels, flooding $20-25 \%$ of the total 
country land. In extreme cases, $50-70 \%$ of the land may be inundated (Irfanullah et al. 2011). Therefore, low-lying areas may be five to eight months waterlogged (BWDB 2012; Irfanullah et al. 2011; Rahman et al. 2007).

Annual floods and waterlogging adversely affects human livelihood, health, education, and causes damage to property, but the most severely impaired is the agricultural sector (Brouwer et al. 2007), which contributes approximately $18 \%$ to its GDP (Gross Domestic Product). Long-term waterlogging (difficulty in growing vegetables, to achieve a successful harvest or to plant vegetables) makes too difficult the life of farming communities which depend for land-based agriculture. This eventually results in economic and social instability, resulting in hunger, malnutrition, depression, disease, unemployment, and social conflicts (Brouwer et al. 2007; Poncelet 2009). Therefore, the people are not only affected temporarily, but also for years afterward following a single disaster. Farming families often end up migrating closer to urban areas (Rayhan \& Grote 2007; Walsham 2010). This unplanned migration also creates a burden on urban environments and has triggered problems such as overcrowding, health and sanitation crises, waste management, environmental pollution, traffic jams, esthetic impairments, and various social conflicts (Chowdhury \& Moore 2017). Therefore, it is evident that due to flooding and waterlogging, Bangladesh is steadily losing the farmers who have been the mainstay of what is a largely agricultural economy as well as disturbing the overall economic, social, and environmental development. Through MIKE11-GIS hydrodynamic and generic binary decision model analysis suggested that the central and northeastern regions of Bangladesh are at higher risk in terms of the depth and spatial extent of flooding (Mirza et al. 2003). Besides, Chowdhury and Moore (2017) and Kundzewicz et al. (2008) anticipated the increasing of flood magnitudes and waterlogging in the future.

In this scenario, development and adoption of alternative farming practices in waterlogged areas may hold great promise. In some waterlogged regions, farmers are utilizing a 100 years old unique traditional technique known as 'floating agriculture' or soilless agriculture (Islam \& Atkins 2007) where seasonal vegetable plants can be grown on the water in a bio-land or floating bed of water-hyacinth, algae and other plant residues (Winterborne 2005). According to their needs, people in different parts of Bangladesh have adopted, modified and named this practice differently (Irfanullah et al. 2011; Islam \& Atkins 2007), such as baira, boor, dhap, gathua, gatoni, geto, kandi, and vasomanchash, or floating agriculture; all these names representing the same traditional cultivation practice. Today this practice is most successful in the coastal areas adjacent to the sea-bank, which remain submerged for long periods especially in the monsoon season, as well as the wetland haor areas, which also remain flooded for long periods (Irfanullah et al. 2011). However, the awareness of possible benefits and suitability of this practice is still very low among Bangladeshi farmers.

While waterlogging has been causing a problem to crop production, adoption of soilless agriculture may hold a promise of adaptation to this situation (Chowdhury $\&$ Moore 2017). Aquaculture is a fast-growing sector of the country's food economy and is ranked fifth in world aquaculture production (FAO 2018), thus integrating with hydroponics agriculture may hold a greater potential to cope with these vulnerabilities (Haq et al. 2004; Islam \& Atkins 2007). Incorporation of fish under existing farming systems could potentially increase productivity and profit. However, the effectiveness of this system is yet to be investigated comprehensively under different open water conditions with enclosures and as well in controlled pond condition. As a maiden study, research had been conducted in pond conditions simulating waterlogged situations. Therefore, this research explores the suitability of integrating the indigenous practice of hydroponics with fish culture.

\section{MATERIALS AND METHODS}

\section{EXPERIMENTAL SITE AND POND PREPARATION}

Three ponds of about $100 \mathrm{~m}^{2}$ each were selected from the pond complex $\left(24^{\circ} 02^{\prime} 04.4^{\prime \prime} \mathrm{N} 90^{\circ} 23^{\prime} 56.3^{\prime \prime} \mathrm{E}\right)$ of Faculty of Fisheries, Bangabandhu Sheikh Mujibur Rahman Agricultural University for conducting a fivemonth (mid-April to early-September) growth experiment. Before setting up experiments ponds were dewatered with pumps, unwanted aquatic vegetation was removed by uprooting from pond bottom and bank, and sundried for seven days. After that, the pond bottom was treated with lime $\left(\mathrm{CaCO}_{3}\right)$ at a rate of $247 \mathrm{~kg} \mathrm{ha}^{-1}$ (Ali et al. 2016) to improve soil structure and destroy pathogenic organisms (Boyd \& Pippopinyo 1994). Each pond was then divided into three equal compartments as replicates using bamboo poles and polyethylene sheets to prevent mixing of water and fish during the experimental period. Then, all sections were watered with pumped underground water and left for a further seven days before fish stocking to allow disturbed clay particles to settle.

\section{PREPARATION OF FLOATING VEGETABLE BEDS}

For each replicate, one floating vegetable bed was constructed using available aquatic weeds, mainly water hyacinths (Eichhornia crassipes), soil, and bamboo. The first layer was prepared with as much matured water hyacinths sufficient to tolerate a man's weight on the water surface. A second layer of water hyacinths (one-fourth of the previous layer) was added after 7-10 days with the addition of bamboo between the two layers to make the bed more stable. As a final layer, semi-decomposed aquatic plants such as duckweed and immature water hyacinths with soil (10 cm thick) were added on the top of the bed to 
speed up the decomposition and left for another 5-7 days (Figure 1). Floating bed preparation followed published literature (Haq et al. 2004; Islam \& Atkins 2007) and personal discussion with local farmers. The size of each experimental floating vegetable bed was $4.5 \mathrm{~m}$ in length,
$1.5 \mathrm{~m}$ in width, and about $30-40 \mathrm{~cm}$ height above the water level. Each floating bed was fixed by bamboo poles at the edge of each experimental compartment for easy maintenance.

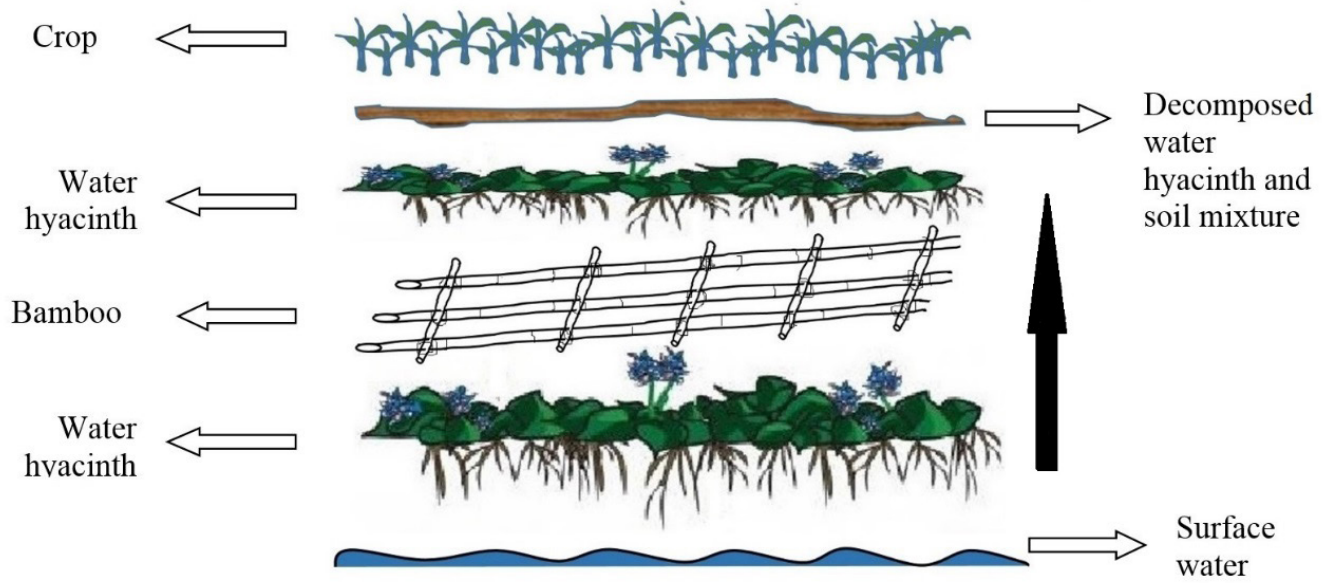

FIGURE 1. Floating bed preparation steps and materials used. The black arrow indicates the order of piling floating bed materials over water surface during bed preparation

\section{SELECTION OF SPECIES AND EXPERIMENTAL SET-UP}

A hardy and a non-hardy fish species was selected to learn the type best suited to floating vegetable bed system. Tilapia (Oreochromis niloticus) is a known hardy species which can grow and survive in various environmental conditions (Hussain et al. 1989). Silver barb is considered as a non-hardy species with limited capability to withstand a wide range of environmental variation (Shamsuddin et al. 2012). Therefore, the fast-growing popular aquaculture species, Genetically Improved Farmed Tilapia (GIFT) strain of Bangladesh Fisheries Research Institute (BFRI) (Hussain et al. 1987) and silver barb (Barbonymus gonionotus) were chosen. High quality fingerlings of monosex GIFT and silver barb were collected from BFRI hatchery and brought to the experimental ponds in oxygenated polyethylene bags and acclimated for about 1 hour with pond water before stocking at the rate of $3 \mathrm{~m}^{-2}$ $\left(29981 \mathrm{ha}^{-1}\right.$ ). Three treatments were used viz. SB (silver barb), T (GIFT) and SBT (GIFT and silver barb = 1:1) in each pond. Average initial weights of silver barb and tilapia were not significantly different $(p=0.40)$ among the treatments during stocking.

The vegetable species were selected on the basis of the fish culture period best fit with the season and that has been used in floating bed systems (Haq et al. 2004). The species Indian spinach Basella alba $\left(1.9 \mathrm{~kg} \mathrm{ha}^{-1}\right)$ Okra Abelmoschus esculentus (4.5 $\mathrm{kg} \mathrm{ha}^{-1}$ ), Kalmi Ipomoea aquatica (1.9 $\left.\mathrm{kg} \mathrm{ha}^{-1}\right)$ and Red amaranth Amaranthus gangeticus $\left(0.7 \mathrm{~kg} \mathrm{ha}^{-1}\right)$ were planted and sown on each floating vegetable bed with the same process in equal proportions of allotted area and at equal density in each replication.

\section{GROW-OUT MANAGEMENT}

Fishes were fed twice daily (early morning and afternoon) with floating commercial pellets (protein 30\%) at the rate of $3 \%$ of body weight. The amount of feed was determined at each fifteen day's interval from the calculation of biomass at periodical sampling of fish weight and length. Fish length and weight were recorded using measuring board-scale and electronic balance (ZSA 120, Scientech, USA). Selected vegetables seed and seedlings were planted on bed after fifteen days of fish stocking. No fertilizer was applied either for fish or vegetables. Water quality parameters including temperature, $\mathrm{pH}$, dissolved oxygen (DO), ammonia and fish growth parameters (length and weight) were recorded fortnightly in the morning from 9:00-10:00 am. Water temperature and DO were measured with DO meter (Digital oxygen meter, model DO-5510, Lutron electronic, PA, USA), $\mathrm{pH}$ was measured with Orion Star ${ }^{\mathrm{TM}} \mathrm{A} 221 \mathrm{pH}$ portable meter, Thermo Fisher Scientific, USA and ammonia was measured with ammonia kit (HI-3824 Ammonia test kit, Hanna instruments, USA). Mature vegetables were harvested 
throughout the growing period and data were recorded for calculating final production. Final harvesting of fishes was done at the end of the culture period. Growth parameters viz. survival rate, final individual weight, daily growth rate, $\%$ weight gain and specific growth rate (\% SGR) and net unit production were calculated following Tidwell et al. (2000).

\section{ECONOMIC ANALYSIS}

For the convenience of economic analysis, all expenses were categorized into two main categories as structural and operational costs. Costs for the construction of experimental units using bamboo poles, polyethylene, threads, and labor cost were included as a structural cost. Operational cost included the price for floating vegetable bed preparation, pond preparation, seed, and feed. All calculated income from fish and vegetables were regarded as gross revenue. The net profit was calculated by subtracting total the gross cost from gross revenue. The benefit-cost ratio (BCR) is the ratio of total gross revenue and gross cost. The net profit and cost-benefit ratio (BCR) were estimated from the expenses and income from fish and vegetables of each experimental unit.

\section{DATA ANALYSIS}

Data from the experimental trials were analyzed with Statistica 13.2 software (StatSoft Inc., Tulsa, USA). Normality of data was tested through Shapiro-Wilk tests. Water quality parameters were analyzed using repeated measures ANOVA, while growth parameters and yield of fish (survival rate, final individual weight, daily growth rate, $\%$ weight gain and specific growth rate $(\%$ SGR), net unit production) and vegetable production rate were tested using one-way analysis of variance (ANOVA). Significant variation among the treatments for any parameter were determined through post-hoc Tukey HSD test at $5 \%$ level of significance $(P<0.05)$. An economic analysis was conducted to determine the economic feasibility of this technology for rural farmers (Shang 1990). Total operational cost, Gross revenue, net profit, and BCR were analyzed through Kruskal-Wallis ANOVA. Data were presented as mean \pm SD.

\section{RESULTS}

\section{WATER QUALITY PARAMETERS}

The observed water quality parameters temperature, dissolved oxygen, $\mathrm{pH}$, and ammonia were not significantly different $(p=0.29)$ among different treatments during the culture period. Over the study period, maximum water temperature $\left(34.53{ }^{\circ} \mathrm{C}\right)$ was recorded in June and minimum $\left(27.17{ }^{\circ} \mathrm{C}\right)$ in May. Lowest dissolved oxygen (DO) values were observed in mid-May and early August among all treatments. A slightly higher ammonia value (2.17) was observed during late June and early July. During the trial period $\mathrm{pH}$ ranges were 7 to 8 in all treatments (Figure S1). The mean values for water quality parameters with standard deviation (SD) in the different treatments are shown in Table 1.

TABLE 1 . Water quality parameters of three treatments over the experimental period. Data presented as mean $\pm \mathrm{SD}$. The minimum and maximum observed values are in the parentheses. SB, silver barb; T, GIFT and SBT, GIFT and silver barb $=1: 1$

\begin{tabular}{lccc}
\hline \multicolumn{1}{c}{ Parameters } & SB & T & SBT \\
\hline Temperature $\left({ }^{\circ} \mathrm{C}\right)$ & $29.63 \pm 1.18$ & $29.93 \pm 2.14$ & $29.88 \pm 2.21$ \\
& $(27.17-33.23)$ & $(27.3-34.23)$ & $(27.3-34.53)$ \\
$\mathrm{pH}$ & $7.32 \pm 0.12$ & $7.29 \pm 0.14$ & $(7.17-7.73)$ \\
& $(7.20-7.57)$ & $(7.17-7.60)$ & $4.69 \pm 1.30$ \\
Dissolved Oxygen, & $4.42 \pm 1.32$ & $4.71 \pm 1.45$ & $(3.2-6.5)$ \\
DO $\left(\mathrm{mg} \mathrm{l}^{-1}\right)$ & $(2.8-6.13)$ & $(2.8-6.5)$ & $1.38 \pm 0.33$ \\
Total $\mathrm{NH}_{3}\left(\mathrm{mg} \mathrm{l}^{-1}\right)$ & $1.52 \pm 0.50$ & $1.45 \pm 0.24$ & $(1.0-2.0)$ \\
& $(0.67-2.17)$ & $(1.0-1.67)$ & \\
\hline
\end{tabular}


GROWTH AND PRODUCTION PERFORMANCE OF FISH AND VEGETABLES

The cumulative mean survival rate of silver barb and tilapia were also not significantly different $(p=0.16)$ in all treatments at the end of the culture period. Final weights or individual weight of fish varied significantly $\left(p=10^{-4}\right)$ among the treatments. Silver barb in monoculture showed lower mean weight than tilapia of T and tilapia and silver barb of SBT. Similarly, daily growth $\left(p=10^{-3}\right), \%$ weight gain $(p=0.01)$ and specific growth rate $(\%$ SGR $)(p=0.001)$ varied significantly among fish of treatments (Table 2 ). Total net unit production of fish was significantly higher $(p=0.0003)$ in T and SBT than SB (Table 2, Figure 2). Total unit production of all vegetables did not vary significantly $(p=0.17)$ among different treatments (Figure 3).

TABLE 2. Mean ( \pm SD) values of growth and expected production of fish species in all treatment (Values in each row with different superscript are significantly different $(\mathrm{p}<0.05)$. SB, silver barb; T, GIFT and SBT, GIFT and silver barb $=1: 1$

\begin{tabular}{|c|c|c|c|c|}
\hline \multirow[t]{3}{*}{ Parameters } & \multicolumn{4}{|c|}{ Treatments } \\
\hline & \multirow{2}{*}{$\frac{\mathrm{SB}}{\text { Silver barb }}$} & \multirow{2}{*}{$\frac{\mathrm{T}}{\text { Tilapia }}$} & \multicolumn{2}{|c|}{ SBT } \\
\hline & & & Tilapia & Silver barb \\
\hline Initial weight (g) & $3.7 \pm 0.3$ & $4.0 \pm 0.4$ & $3.7 \pm 0.3$ & $3.5 \pm 0.4$ \\
\hline Final weight $(\mathrm{g})$ & $163.4 \pm 49.1^{b}$ & $267.8 \pm 56.1^{\mathrm{a}}$ & $300.0 \pm 45.5^{\mathrm{a}}$ & $245.6 \pm 90.7^{\mathrm{a}}$ \\
\hline Survival rate $(\%)$ & $84.3 \pm 2.08$ & $90.7 \pm 4.04$ & $88.3 \pm 3.06$ & $87 \pm 2.65$ \\
\hline Daily growth $\left(\mathrm{g} \mathrm{day}^{-1}\right)$ & $1.07 \pm 0.09^{\mathrm{b}}$ & $1.75 \pm 0.8^{\mathrm{a}}$ & $1.92 \pm 0.2^{\mathrm{a}}$ & $1.61 \pm 0.1^{\mathrm{a}}$ \\
\hline$\%$ weight gain & $4324.7 \pm 357.9^{b}$ & $6585.0 \pm 593.3^{\mathrm{a}}$ & $7603.7 \pm 1226.1^{\mathrm{a}}$ & $6961.3 \pm 862.7^{\mathrm{a}}$ \\
\hline SGR $\left(\%\right.$ day $\left.^{-1}\right)$ & $2.53 \pm 0.06^{\mathrm{b}}$ & $2.77 \pm 0.06^{\mathrm{a}}$ & $2.93 \pm 0.12^{\mathrm{a}}$ & $2.83 \pm 0.05^{\mathrm{a}}$ \\
\hline Net production $\left(\mathrm{kg} \mathrm{ha}^{-1}\right)$ & $4042.6 \pm 383.7^{\mathrm{b}}$ & $7113.6 \pm 238.2^{\mathrm{a}}$ & $3688.5 \pm 496.7^{\mathrm{bc}}$ & $3029.9 \pm 308.8^{c}$ \\
\hline Total net production $\left(\mathrm{kg} \mathrm{ha}^{-1}\right)$ & $16.37 \pm 1.6^{\mathrm{b}}$ & $28.80 \pm 1.0^{\mathrm{a}}$ & 27.2 & \\
\hline
\end{tabular}

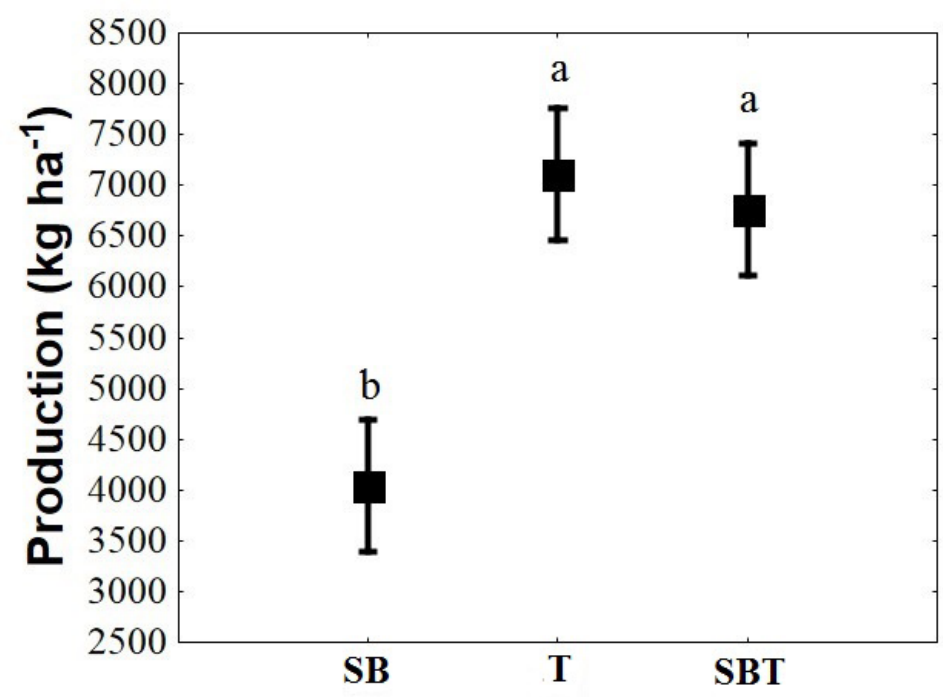

FIGURE 2. Fish production rate of different treatments. SB, silver barb; T, GIFT and SBT, GIFT and silver barb $=1: 1$ 


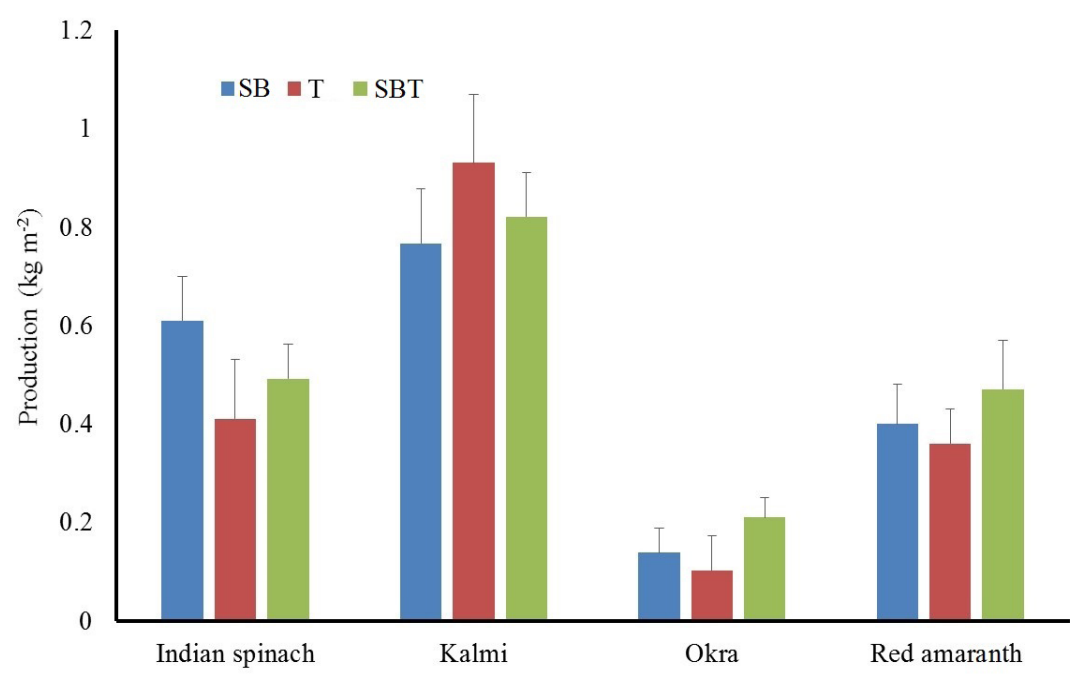

FIGURE 3. Yield of different vegetables in floating bed of different treatments. SB, silver barb; T, GIFT and SBT, GIFT and silver barb $=1: 1$

\section{ECONOMIC ANALYSIS}

The structural cost was $\$ 6.42$ USD for each replication. The operational cost was \$85.31-131.24 USD for different replications which did not vary significantly $(\mathrm{H}=5.65, p$
$=0.06)$ among the treatments. Similarly, gross cost $(\mathrm{H}=$ $5.60, p=0.06)$, net profit $(\mathrm{H}=5.60, p=0.06)$ and benefitcost ratio $(\mathrm{H}=5.61, p=0.06)$ also did not vary significantly among the treatments (Table 3).

TABLE 3. Economic analysis of fish and vegetable production with floating bed agriculture system during five months of trail. SB, silver barb; T, GIFT and SBT, GIFT and silver barb =1:1, R, replication of treatments, \$, US Dollar (1\$ USD = 82 Bangladeshi Taka)

\begin{tabular}{|c|c|c|c|c|}
\hline & \multirow{2}{*}{$\begin{array}{c}\text { Inputs/items } \\
\text { Cost }\end{array}$} & \multicolumn{3}{|c|}{ Cost/revenue (\$ USD) } \\
\hline & & SB & $\mathrm{T}$ & SBT \\
\hline & Polyethylene & 15.61 & 15.61 & 15.61 \\
\hline & Bamboo, threads & 9.62 & 9.62 & 9.62 \\
\hline & Labor cost & 20.98 & 20.98 & 20.98 \\
\hline & Total cost & 46.21 & 46.21 & 46.21 \\
\hline & Per year cost ( 3 years longevity) & 15.40 & 15.40 & 15.40 \\
\hline \multirow[t]{6}{*}{ A } & Structural cost for 5 months & 6.42 & 6.42 & 6.42 \\
\hline & Floating bed preparation & 15.49 & 15.49 & 15.49 \\
\hline & Pond preparation & 5.63 & 5.63 & 5.63 \\
\hline & Fingerling & 14.27 & 14.27 & 14.27 \\
\hline & Feed $($ mean \pm SD) & $52.62 \pm 4.8$ & $91.82 \pm 3.03$ & $88.13 \pm 11.26$ \\
\hline & Vegetables seed/seedlings & 1.22 & 1.22 & 1.22 \\
\hline B & Total cost/ operational cost & 89.234 .8 & $128.43 \pm 3.03$ & $124.74 \pm 11.26$ \\
\hline \multirow[t]{4}{*}{$\mathrm{C}$} & Gross cost $(\mathrm{A}+\mathrm{B})$ & $95.65 \pm 4.8$ & $134.84 \pm 3.02$ & $131.16 \pm 11.26$ \\
\hline & Revenue & & & \\
\hline & Fish production (mean $\pm \mathrm{SD}$ ) & $105.24 \pm 9.6$ & $183.63 \pm 6.06$ & $176.26 \pm 22.53$ \\
\hline & Vegetable production (mean $\pm \mathrm{SD}$ ) & $3.71 \pm 0.27$ & $3.82 \pm 0.21$ & $4.05 \pm 0.25$ \\
\hline $\mathrm{D}$ & Gross revenue (mean $\pm \mathrm{SD}$ ) & $108.96 \pm 9.37$ & $187.46 \pm 6.24$ & $180.31 \pm 22.49$ \\
\hline $\mathrm{E}$ & Net benefit (D-C) (mean \pm SD) & $13.31 \pm 4.58$ & $52.61 \pm 3.21$ & $49.15 \pm 11.23$ \\
\hline $\mathrm{F}$ & Benefit cost ratio $(\mathrm{BCR})=\mathrm{D} / \mathrm{C}($ mean $\pm \mathrm{SD})$ & $1.14 \pm 0.04$ & $1.39 \pm 0.02$ & $1.37 \pm 0.06$ \\
\hline
\end{tabular}


DISCUSSION

Floating gardening has been well established as means of climate change adaption option in haor and waterlogged areas (Irfanullah 2013), creating employment opportunities for both sexes (Haq et al. 2004) as well as sources of subsistence income over the year (Baas \& Ramasamy 2008). Our present research focused on the integration of fish culture with floating bed agriculture systems to better improve the livelihood of waterlogged or longterm flood-affected people. As a first stage we used our experimental ponds to find out the effect of long-term waterlogging conditions with vegetable beds (decomposed and semi-decomposed) on water quality parameters. The recorded water quality parameters did not significantly vary among the treatments and remained within the ideal limit of pond fish culture, tilapia and silver carp (Boyd \& Pippopinyo 1994; Caldini et al. 2011; Mollah et al. 2011). In the present study, levels of total ammonia were also in the suitable range of fish culture (Bhatnagar \& Devi 2013), however, slightly elevated values in June and July might be due to decomposition of used aquatic weeds.

Tilapia and silver barb in different experimental systems with floating vegetable beds showed about $90 \%$ survival which did not vary significantly among the treatments. Former growth studies of tilapia and silver barb in polyculture or cage culture system also presented similar consistent results (Ali et al. 2016; Habib et al. 2015; Mondal et al. 2010). The growth of tilapia was statistically the same in mono- and polyculture, while silver barb showed significantly higher values in polyculture systems. Therefore, total yield was significantly higher in treatments with only tilapia and the two species tilapia and silver barb at 1:1 ratio. Former experiments suggested that silver barb best grow in combination with tilapia and carps (Chaudhary et al. 2008; Haque et al. 1998). In our present experiments, higher growth of silver barb in polyculture might be due to synergistic interactions from fecal input of the two species when cultured together. Higher productivity of silver barb was also reported in monoculture at the stocking density of 24700 (Mollah et al. 2011) and 37050 fish ha-1 (Sarker et al. 2016) in earthen ponds. In our cases, stocking density was about 29981 fish ha- ${ }^{-1}$. Therefore, lower production of silver barb in monoculture system might be related to feed utilization rather than stocking density. Growth rates of tilapia in these experiments also coincide with the findings of others (Ali et al. 2016; Mondal et al. 2010). The best production performance of tilapia in mono and polyculture system indicates its potentiality for integration in floating bed agriculture systems. It was expected that tilapia would be ideal fish species for floating bed agriculture systems due to their wide range of environmental adaptation capability and tolerance (Chervinski 1982).

In the present experiments, the four selected vegetables already had been proven suitable in waterlogged areas of floating bed systems in Bangladesh were grown on the floating bed of experimental units (Chowdhury
\& Moore 2017). The selected vegetable production did not significantly differ among the treatments. The tested vegetables or others could be used in different locations and time during integration with fish culture.

For successful planning of aquaculture business and identification of economic sustainability, economic analysis is an important management tool (Ali et al. 2016). Among the three treatments, there was no significant differences in structural cost, total or gross cost. In the same way, there were no significant differences in revenue earned from fish and vegetables or total gross revenue, in net profit and benefit-cost ratio among the treatments. Considering the BCR ratio all treatments were economically efficient. Nevertheless, tilapia monoculture (T) and tilapia with silver barb (SBT) showed a mathematically higher average net profit in floating vegetable bed systems. We could conclude that both species showed suitability for integration with the proposed system, though tilapia monoculture or silver barb and tilapia mixed culture is economically more valued. It is already confirmed in other research that integration of agricultural crops with fish culture systems has higher economic efficiency than the main agricultural crops of Bangladesh (Afroz \& Islam 2012). The cost-benefit analysis showed that the floating vegetable bed practice is economically viable with fish culture. However, the present experiments were simulations of waterlogged areas in pond conditions. Therefore, more research is needed in a real environment with the inclusion of affected people which could provide more realistic data to overcome the sufferings of associated populations.

\section{CONCLUSION}

We can conclude that floating bed agricultural integration with aquaculture offers a practical solution to poverty and land scarcity. It can provide a win-win system in waterlogged areas of Bangladesh which give higher agricultural yield without the application of chemical fertilizers and pesticides. The age-old traditional agricultural knowledge could have potential also to adapt and mitigate climate change through their agroecological features. On the other hand, the integration approach is low-cost, energy-efficient and based on locally available resources. Besides mitigating climate change, it is also helpful for human health safety, natural resource management, energy conservation, and socioecological integrity as well as also enhancing agricultural sustainability. Moreover, as a whole, it could be adopted across the world in regions of similar climatic condition with available resources.

\section{ACKNOWLEDGEMENTS}

The authors are grateful to Bangladesh Agricultural Research Council of Bangladesh for funding this research. The first author would also like to thank the Ministry of Education, Youth and Sports of the Czech Republic 
- projects CENAKVA (No.CZ.1.05/2.1.00/01.0024), CENAKVA II (No. LO1205 under the NPU I program) and the Grant Agency of University of South Bohemia No. 012/2016/Z and No. 017/2016/Z and Ministry of Agriculture of the Czech Republic (project no. QJ1510119) for financial support to the author during the manuscript preparation. All authors declare that they have no conflict of interest. MJA develop the concept, fund acquisition and review the draft manuscript. MSH conduct the experiment, data curation, data analysis, drafting and review the manuscript.

\section{REFERENCES}

Afroz, S. \& Islam, M.S. 201. Economics of aus rice (Oryza sativa) and jute (Corchorus olitorius) cultivation in some selected areas of Narsingdi district of Bangladesh. The Agriculturists 10(2): 90-97.

Ali, H., Haque, M.M., Murshed-e-Jahan, K., Rahi, M.L., Ali, M.M., Al-Masud, M. \& Faruque, G. 2016. Suitability of different fish species for cultivation in integrated floating cage aquageoponics system (IFCAS) in Bangladesh. Aquaculture Reports 4: 93-100.

Baas, S. \& Ramasamy, S. 2008. Community Based in Action. Food and Agricultural Organization of the United Nations (FAO).

Bhatnagar, A. \& Devi, P. 2013. Water quality guidelines for the management of pond fish culture. International Journal of Environmental Sciences 3(6): 1980-2009.

Boyd, C.E. \& Pippopinyo, S. 1994. Factors affecting respiration in dry pond bottom soils. Aquaculture 120(3-4): 283-293.

Brouwer, R., Akter, S., Brander, L. \& Haque, E. 2007. Socioeconomic vulnerability and adaptation to environmental risk: A case study of climate change and flooding in Bangladesh. Risk Analysis 27(2): 313-326.

BWDB. 2012. Annual report Journal of Cleaner Production. Dhaka: Flood Forecasting and Warning Centre, Bangladesh Water Development Board (BWDB).

Caldini, N.N., Rebouças, V.T., Cavalcante, D.D.H., Martins, R.B. \& Sá, M.V.D.C. 2011. Water quality and Nile tilapia growth performance under different feeding schedules. Acta Scientiarum. Animal Sciences 33(4): 427-430.

Chaudhary, S., Shrestha, M., Jha, D. \& Pandit, N. 2008. Growth performance of silver barb (Puntius gonionotus) in mono and polyculture systems. Our Nature 6(1): 38-46.

Chervinski, J. 1982. Environmental physiology of tilapias. The Biology and Culture of Tilapia. Proceedings of the 7th ICLARM Conference, Manila, Philippines.

Chowdhury, R.B. \& Moore, G.A. 2017. Floating agriculture: A potential cleaner production technique for climate change adaptation and sustainable community development in Bangladesh. Journal of Cleaner Production 150: 371-389.

FAO. 2018. The state of world fisheries and aquaculture. Contributing to Food Security and Nutrition for All. Rome: Food \& Agriculture Org. p. 227.

Habib, K., Newaz, A., Badhon, M., Naser, M. \& Shahabuddin, A. 2015. Effects of stocking density on growth and production performance of cage reared climbing perch (Anabas testudineus) of high yielding vietnamese stock. World Journal of Agricultural Science 11(1): 19-28.
Haq, A., Ghosal, T.K. \& Ghosh, P. 2004. Cultivating wetlands in Bangladesh. Leisa Magazine 20(4): 18-20.

Haque, S., Wahab, M., Wahid, M. \& Haq, M. 1998. Impacts of Thai silver barb (Puntius gonionotus Bleeker) inclusion in the polyculture of carps. Bangladesh Journal of Fisheries Research 2(1): 15-22.

Hussain, M.G., Rahman, M.A., Akteruzzaman, M. \& Kohinoor, A.H.M. 1989. A study on the production of Oreochromis niloticus (Linneus) in semi-intensive system in Bangladesh. Bangladesh Journal of Fisheries Research 12(1): 59-65.

Hussain, M., Obaidullah, M., Rahman, M., Akhteruzzaman, M. \& Perschbacher, P. 1987. Hormone induced ovulation and spawning of Puntius gonionotus (Bleeker). The 12 Annual Bangladesh Science Conference, Dhaka, Bangladesh, 10-14 January 1987.

IPCC. 2012. Managing The Risks of Extreme Events and Disasters to Advance Climate Change Adaptation. New York: Cambridge University Press.

Irfanullah, H. 2013. The 'moving sown fields': Anyone interested. SILnews 63: 22-23.

Irfanullah, H., Azad, M., Kamruzzaman, M. \& Wahed, M. 2011. Floating gardening in Bangladesh: A means to rebuild lives after devastating flood. Indian Journal of Traditional Knowledge 10(1): 31-38.

Islam, T. \& Atkins, P. 2007. Indigenous floating cultivation: A sustainable agricultural practice in the wetlands of Bangladesh. Development in Practice 17(1): 130-136.

Kundzewicz, Z.W., Mata, L.J., Arnell, N.W., Döll, P., Jimenez, B., Miller, K., Oki, T., Şen, Z. \& Shiklomanov, I. 2008. The implications of projected climate change for freshwater resources and their management. Hydrological Sciences Journal 53(1): 3-10.

Mirza, M.M.Q., Warrick, R. \& Ericksen, N. 2003. The implications of climate change on floods of the Ganges, Brahmaputra and Meghna rivers in Bangladesh. Climatic Change 57(3): 287-318.

Mollah, M., Moniruzzaman, M. \& Rahman, M. 2011. Effects of stocking densities on growth and survival of Thai Sharpunti (Barbonymus gonionotus) in earthen ponds. Journal of Bangladesh Agricultural University 9(2): 327-338.

Mondal, M., Shahin, J., Wahab, M., Asaduzzaman, M. \& Yang, Y. 2010. Comparison between cage and pond production of Thai climbing perch (Anabas testudineus) and tilapia (Oreochromis niloticus) under three management systems. Journal of Bangladesh Agricultural University 8(2): 313-322.

Poncelet, A. 2009. Bangladesh Case Study Report: The Land of Mad Rivers. EACH-FOR Case Study Report.

Rahman, A.A., Alam, M., Alam, S.S., Uzzaman, M.R., Rashid, M. \& Rabbani, G. 2007. Risks, Vulnerability and Adaptation in Bangladesh. Human Development Report.

Rayhan, I. \& Grote, U. 2007. Coping with floods: Does rural-urban migration play any role for survival in rural Bangladesh. Journal of Identity and Migration Studies 1(2): 82-98.

Sarker, B., Rahman, M. \& Amin, M.R. 2016. Effects of stocking density on growth and production of silver barb (Barbonymus gonionotus) in pond. The Agriculturists 14(2): 61-66.

Shamsuddin, M., Hossain, M.B., Rahman, M.M., Asadujjaman, M. \& Ali, M.Y. 2012. Performance of monosex fry 
production of two Nile tilapia strains: GIFT and NEW GIPU. World Journal of Fish and Marine Scienc 4: 68-72.

Shang, Y.C. 1990. Aquaculture Economic Analysis: An Introduction. Los Angeles: World Aquaculture Society.

Tidwell, J.H., Coyle, S.D., VanArnum, A., Weibel, C. \& Harkins, S. 2000. Growth, survival, and body composition of cagecultured Nile tilapia Oreochromis niloticus fed pelleted and unpelleted distillers grains with solubles in polyculture with freshwater prawn Macrobrachium rosenbergii. Journal of the World Aquaculture Society 31(4): 627-631.

Walsham, M. 2010. Assessing the Evidence: Environment, Climate Change and Migration in Bangladesh. International Organization for Migration (IOM). Regional Office for South Asia.

Winterborne, J. 2005. Hydroponics: Indoor Horticulture. Surrey: Pukka Press.
Md. Shakhawate Hossain* \& Md. Jahangir Alam

Department of Fisheries Biology and Aquatic Environment

Bangabandhu Sheikh Mujibar Rahman Agricultural University

Gazipur, 1706

Bangladesh

Md. Shakhawate Hossain*

Faculty of Fisheries and Protection of Waters

University of South Bohemia in České Budějovice

Zátiší 728/II, Vodňany, 38925

Czech Republic

*Corresponding author; email: shakhawate@bsmrau.edu.bd

Received: 27 February 2019

Accepted: 27 March 2020 
Water Quality Parameters

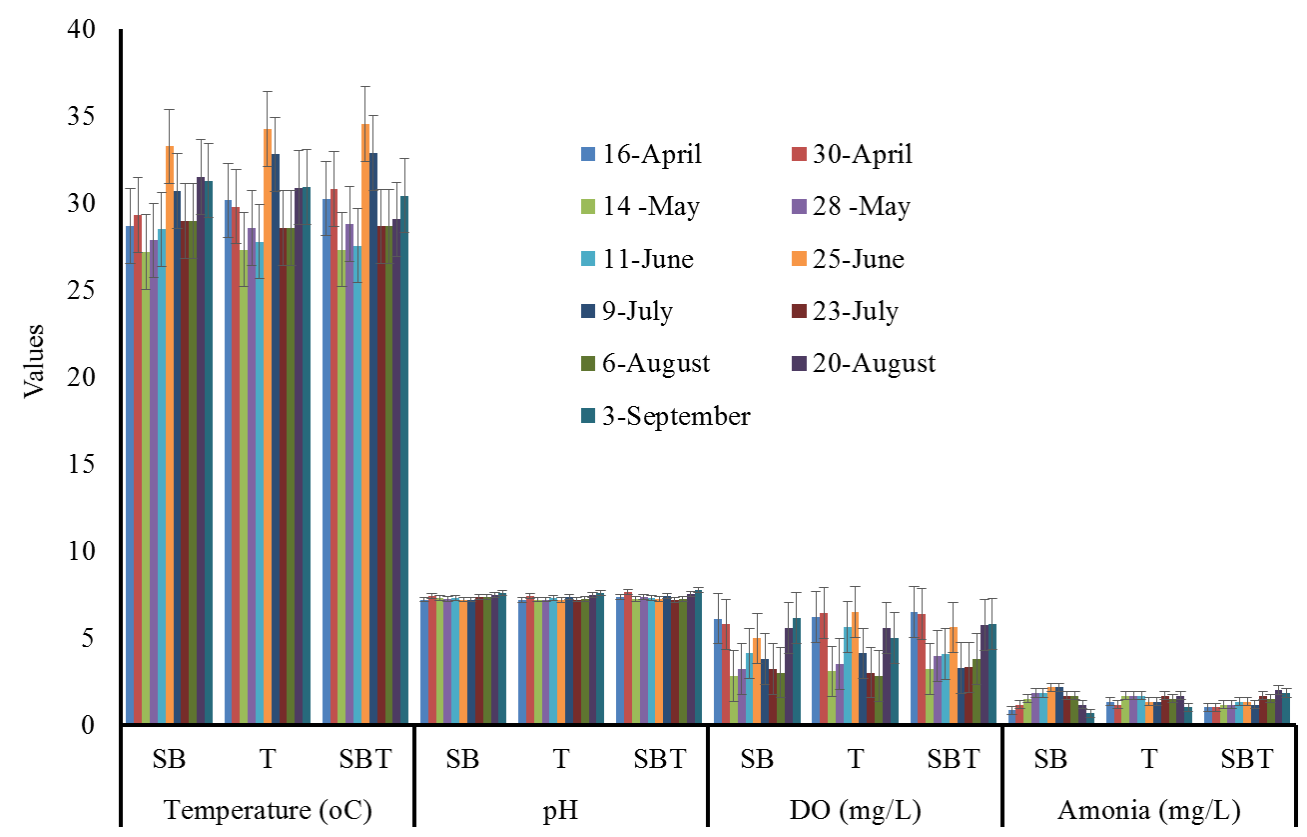

FIGURE S1. Water quality parameters (Mean $\pm \mathrm{SD}$ ) of three treatments at different sampling day over the experimental period (16th April - 3rd September). SB, silver barb; T, GIFT and SBT, GIFT and silver barb $=1: 1$ 